\title{
As escolas de samba do Rio de Janeiro (2011-2020): carnaval e resistência
}

\author{
Maximiliano Marques \\ Felipe Ferreira
}

\begin{abstract}
Resumo
Este artigo investiga os desfiles das escolas de samba do Rio de Janeiro em seu diálogo com a política brasileira no período de 2011 a 2020, considerando-os um importante espaço de discussão e negociação entre a sociedade e as instituições de poder. Propõe-se também revisar as tensões ocorridas no Brasil ao longo dessa fase e que serviram como fonte de inspiração para as escolas de samba cariocas manifestarem as desigualdades econômicas, sociais e políticas do país, de forma crítica e satírica. Ao final, argumenta que, por representar uma época de grande movimentação política nacional, o referido periodo refletiu a revalorização da ideia de "resistência" nas narrativas visuais (fantasias e alegorias) e literárias (letras dos sambas e enredos) do carnaval das escolas de samba.
\end{abstract}

\begin{abstract}
This article investigates the pageants of Rio de Janeiro's samba schools in terms of their dialogue with Brazilian politics from 2011 to 2020, considering them an important space for discussion and negotiation between the society and the institutions of power. It also explores the tensions that have occurred in Brazil during this phase and which have served as a source of inspiration for the city's samba schools to express the country's economic, social and political inequalities in a critical and satirical way. Finally, this article argues that the period in question, which represents a time of major shifts in national politics, has led to the re-evaluation of the idea of "resistance" in the visual (costumes and floats) and literary narratives (lyrics of sambas and themes) of the carnival of samba schools.
\end{abstract}


O presente artigo visa investigar de que forma as escolas de samba do Rio de Janeiro dialogaram com a política no Brasil entre 2011 e 2020, período marcado por numerosas tensões no país, entre elas: (1) o primeiro mandato da presidente Dilma Rousseff, de 2011 a 2014; (2) os protestos nacionais realizados a partir de 2013; (3) a Operação Lava Jato, deflagrada em 2014; (4) o começo do segundo mandato de Rousseff em 2015, após ser reeleita em disputa acirrada que polarizou o país; (5) seu impeachment em 2016; (6) o governo transitório do presidente Michel Temer no mesmo ano; e (7) a eleição do presidente Jair Bolsonaro em 2018. Esse conjunto de acontecimentos serviu, na época, como fonte de inspiração para os desfiles de várias escolas de samba cariocas que criticavam as desigualdades econômicas, sociais e políticas do país.

Sob esse prisma, destacamos as manifestações carnavalescas como atores importantes na construção da sociedade (Ferreira, 2012), focalizando o espaço da cultura popular como uma arena de disputa entre diferentes narrativas (Hall, 2003), um processo marcado não somente por "resistências", mas também por "incorporações" (Storey, 2015). Com base nessas considerações, concebemos a linguagem do carnaval das escolas de samba a partir de seu caráter crítico (Bakhtin, 1998, 2010), visando ressaltar, em nossa abordagem, mensagens de protesto e ironia presentes tanto nas letras de sambas-enredo quanto em expressões visuais de desfiles das principais agremiações do Rio de Janeiro, em busca de uma perspectiva alternativa ao trabalho desenvolvido por Augras (1998).

Bakhtin (2010), ao destacar a crítica e o deboche como elementos definidores das festas carnavalizadas do fim da Idade Média e do início do Renascimento na Europa - que incluem o carnaval propriamente dito, bem como "as diversas festividades, rituais e formas do tipo carnaval" (Id., 1998, p. 250) -, abre caminho para uma leitura política das diversas manifestações carnavalescas. Estas se aproveitariam das liberdades ligadas ao período festivo para apresentar uma espécie de "reação possível" (e limitada no tempo) das camadas populares às imposições dos grupos dominantes. A “inversão do mundo", característica do momento carnavalesco, seria, portanto, uma forma de crítica teatralizada ao poder constituído. Cabe mencionar que os Estudos Culturais ingleses incorporaram a contribuição bakhtiniana a suas discussões sobre a relação entre as expressões culturais populares e o poder dominante, com destaque para as considerações de Hall (2003). O autor afirma que a cultura popular é local de luta contra a cultura dos poderosos e "o prêmio a ser conquistado ou perdido nessa luta" (Ibid., p. 263), reforçando seu papel de arena, de espaço de enfrentamento entre o consentimento e a resistência. É a partir desse enfrentamento, resumido por Storey (2015) no conceito gramsciano de hegemonia, que se estabelece aquilo que Ferreira (2005) define como "lugar do carnaval". Nas palavras do autor (2005, p. 319), 
“a festa se define por meio da própria luta estabelecida por ela. É esse confronto complexo, essa disputa pela determinação do fato festivo, que propiciará sua própria existência". Nesse sentido, Ferreira propõe que “a festa carnavalesca seja entendida como um caso particular de festa, definido como o produto da disputa de espaço/poder estabelecida para se determinar aquilo que foi denominado como 'o lugar do carnaval'"' (Ibid.). À vista disso, tratamos os desfiles das escolas de samba neste artigo tanto como agentes de transformação da sociedade quanto como lugar de discussão de poder.

Nessa perspectiva, dividimos o trabalho em três partes. Na primeira delas, apresentamos o carnaval das escolas de samba do Rio de Janeiro como um espaço de negociação estabelecido desde seu surgimento na cidade, na década de 1930. Em seguida, revisamos, de forma breve, as turbulências políticas ocorridas no país no período 2011-2020, em busca de destacar, finalmente, sua presença nas narrativas visuais (fantasias e alegorias) e literárias (letras dos sambas e enredos ${ }^{1}$ ) dos desfiles das agremiações.

\section{Lugar de negociação: as escolas de samba do Rio de Janeiro}

Afastando-nos de boa parte da historiografia do samba, que procura explicar o surgimento das escolas de samba a partir da concepção evolucionista fixada nos anos 1950 por Eneida de Moraes (1958), na qual os ranchos e cordões seriam espécies de "precursores" das agremiações (Cabral, 1996; Valença, 1996; Costa, 2000; Lira Neto, 2017); e buscando um caminho diferente da visão antropológica de Goldwasser (1975), DaMatta (1998) e Cavalcanti (2008), aproximamo-nos da perspectiva da História Cultural (Cunha, 2001; Ferreira, 2004, 2008; Pereira, 2004), ressaltando as diversas contingências que reestabelecem continuamente os significados das manifestações carnavalescas.

Desde o início do século XX, foi estabelecido um processo de "organização" da folia, a fim de definir paradigmas capazes de tornar compreensíveis e "palatáveis" as numerosas expressões do carnaval provenientes do século anterior, reunidas naquilo que Ferreira (2004) denomina "confusão carnavalesca". Tais ações podem ser exemplificadas pelas atividades jornalísticas (por meio dos concursos, da organização de exposições de estandartes e das descrições da folia das ruas), bem como pelo interesse crescente dos folcloristas pelo carnaval. Buscando o reconhecimento e a valorização de suas atividades, os

\footnotetext{
${ }^{1} \mathrm{O}$ "enredo" de uma escola de samba é a história contada em seu desfile, consistindo em duas partes: a primeira delas é sua descrição, apresentada aos jurados em um caderno intitulado "Abre Alas"; a segunda é o desenvolvimento do tema, por meio das fantasias, dos elementos alegóricos e das performances presentes no desfile.
} 
grupos carnavalescos populares, acomodaram-se, pouco a pouco, às descrições, regras e premiações cada vez mais frequentes. É dentro desse processo de “diálogo" que, no fim da década de 1920, a intelectualidade brasileira começou a repercutir no país a verdadeira onda de valorização da cultura negra que tomou conta da Europa e dos Estados Unidos anos antes, conhecida pelo nome de negrofilia (Blake, 1999; Archer-Straw, 2000).

O interesse por tudo que fosse ligado à negritude e às raízes africanas, manifestado, por exemplo, na ascendência do jazz e da arte moderna (Picasso, Modigliani, Tarsila do Amaral...), associado ao desgaste dos ranchos carnavalescos, criticados, na época, pelo excesso de luxo e pelo intelectualismo dos seus enredos, acabou por abrir espaço para grupos oriundos dos morros cariocas, caracterizados pelo surgimento de um novo ritmo, o samba batucado.

Formados quase exclusivamente por moças e rapazes de ascendência afro-brasileira, em geral moradores ou frequentadores das favelas da periferia do Centro do Rio de Janeiro, esses grupos de samba de morro no início da década de 1930 passaram a ser reconhecidos pelo nome de escolas de samba. Desde então, o forte apelo popular e a origem humilde de seus integrantes, associados à notável presença negra e ao ritmo sincopado do samba (derivado do batuque produzido por diferentes instrumentos de percussão), despertaram o interesse da elite cultural brasileira. Nesse contexto, as características fortemente populares do carnaval e, em particular, das escolas de samba, se encaixavam perfeitamente no padrão negro-popular desejado pela elite pensante da então capital do Brasil. Pouco tempo depois, na década de 1940, começariam a se configurar alguns dos personagens que marcaram a identidade do país, entre os quais o malandro, a mulata e a baiana, ${ }^{2}$ difundidos internacionalmente pela imagem do "Brasil, País do Carnaval", resumida no ícone hollywoodiano Carmen Miranda (Ferreira, 2004) e nos conceitos de sensualidade, pureza, tradição e negritude.

O contato da elite cultural com as camadas populares incentivava, cada vez mais, o diálogo entre os interesses da população dos morros e subúrbios cariocas e aqueles da intelectualidade, fazendo com que as escolas de samba passassem a se relacionar também com o governo, apresentando desfiles com temas patrióticos que enalteciam o país e a figura do presidente Getúlio Vargas. ${ }^{3}$

\footnotetext{
${ }^{2}$ Sobre a construção simbólica da personagem baiana de escola de samba, ver também Araújo (2011).

${ }^{3}$ Em 1942, por exemplo, com o Brasil já envolvido na Segunda Guerra Mundial, a apresentação do enredo "A vida do samba", da escola de samba Portela, contou com um carro alegórico saudando abertamente o presidente Vargas (Ferreira, 2008, 2012). Três anos depois, a mesma agremiação desfilou com o enredo
} 
As escolas de samba aceitavam, com prazer, o apoio do governo federal, em troca das louvações ao Estado e ao presidente, visto que essa aproximação com o poder constituído dava aos sambistas uma aura de respeitabilidade responsável por sua aceitação crescente por parte da sociedade. Com isso, as escolas de samba assumiram o papel de legítimas e principais representantes da "tradicionalidade" e da "singeleza" esperadas das manifestações da cultura popular, sem deixar de incorporar as novidades que eram fundamentais nas disputas entre elas, marcadas por concursos que apontavam, a cada ano, a campeã dos desfiles. Segundo Ferreira (2012, p. 176-177):

As escolas incorporaram paulatinamente novos significados a seus elementos "tradicionais", reformulando seus sambas, enredos, fantasias, alegorias e até sua forma de desfile. À ideia de tradição incorporava-se o conceito de resistência. Isso sem perder a "pureza" original, nem abrir mão das novidades tão essenciais às disputas acirradas pela vitória no campeonato carnavalesco. A modernização dos meios de comunicação marcada pela difusão do rádio, pelas revistas semanais ilustradas, pelos jornais da tela nos cinemas e, pouco depois, pela televisão ampliará o interesse do país pelas escolas de samba cariocas. [...]. Embora tivessem se reformulado de forma radical, as escolas de samba haviam tido sucesso em negociar significados e formas, de modo a manter sua tradicionalidade em novos modos de expressão.

Só a partir da década de 1960, entretanto, as escolas de samba se transformaram na festa máxima do carnaval brasileiro, com a presença de alegorias cada vez maiores e fantasias mais luxuosas ano a ano, ressignificando seus elementos "tradicionais" mediante negociações em várias escalas de influência (com destaque para o teatro de revista de Walter Pinto; os espetáculos de Carlos Machado; o cinema hollywoodiano; os shows dos cabarés parisienses do Moulin Rouge e Folies Bergère; e os musicais da Broadway), mostrando, assim, sua abertura para o diálogo e sua notável capacidade de adaptação e permeabilidade a incorporações. Contudo, diversas personalidades ligadas ao carnaval, tais como Pamplona (2013, p. 54, 78 e 79), Candeia e Isnard (1978, p. 70) e Newton de Sá (apud Cabral, 1996, p. 186), consideram que a influência desses meios culturais nacionais e internacionais sobre as escolas de samba estavam, na época, afastando-as de sua raiz popular e singela, pensamento

\footnotetext{
"Brasil glorioso", louvando o país nos seguintes versos do seu samba: "Ó meu Brasil glorioso / És belo, és forte, um colosso / É rico pela natureza / Eu nunca vi tanta beleza / Foi denominado terra de Santa Cruz / Ó pátria amada, terra adorada, terra de luz / Nessas mal traçadas rimas / Quero homenagear / Este meu torrão natal / És rico, és belo, és forte / E por isso és varonil / Ó pátria amada, terra adorada, viva o Brasil" (samba de autoria de Ventura. Disponível em http://www.gresportela.org.br/Historia/DetalhesAno?ano=1945.
} Acesso em: 10 abr. 2021). 
que, a nosso ver, caminha na contramão da pluralidade e do dinamismo da cultura popular. Sobre esse aspecto, Hall (2003, p. 257) destaca a importância das relações "que colocam a 'cultura popular' em uma tensão contínua (de relacionamento, influência e antagonismo) com a cultura dominante". Essa lógica da cultura popular permite-nos pensá-la "como uma mistura 'negociada' do que 'vem de cima' com o que 'vem de baixo', do 'comercial' e do 'autêntico'; um equilíbrio mutável de forças entre resistência e incorporação' (Storey, 2015, p. 172). Nesse sentido, observamos que a transformação das escolas de samba em um show de grande porte destoava de suas características tidas como autênticas, porém lhes trazia um novo sentido, uma nova ressonância cultural, resultante de sua interação com elementos da contemporaneidade, em reflexo à dramaturgia e ao meio urbano do período. Essas características, que as escolas de samba vêm demonstrando ao longo de sua trajetória quase centenária, se destacaram na última década, marcada por grande instabilidade política no país, propiciando o florescimento dos chamados enredos críticos e revalorizando a ideia de "resistência" em seus desfiles.

\section{Resistência: as tensões políticas no Brasil (2011-2020)}

Foram numerosos os fatos que impactaram a política brasileira no período de 2011 a 2020, marcado, inicialmente, pela vitória de Dilma Rousseff nas eleições presidenciais. ${ }^{4}$ Embora estivesse com a popularidade em alta no começo do seu mandato, Rousseff passou a enfrentar uma desaceleração econômica no país em 2013, quando protestos contra o aumento das tarifas de transporte público tomaram as ruas das principais cidades brasileiras, contando com a participação de mais de um milhão de pessoas. Essas manifestações criticavam também a corrupção, a impunidade, a PEC $37^{5}$ e o excesso de gastos do governo federal com a construção e reforma de estádios de futebol para a Copa do Mundo no Brasil (que seria realizada em 2014), reivindicando melhorias nas áreas de saúde e educação (Cabral, 2013).

O ano de 2014 foi marcado por uma onda de novos protestos, bem como pelo início das investigações da Operação Lava Jato, da Polícia Federal, que visava apurar desvios de recursos públicos e lavagem de dinheiro na maior estatal brasileira, a Petrobras, envolvendo

\footnotetext{
${ }^{4}$ Após atuar como ministra de Minas e Energia (2003-2005) e ministra-chefe da Casa Civil (2005-2010) ao longo do governo do ex-presidente Luiz Inácio Lula da Silva (2003-2010), do Partido dos Trabalhadores (PT), Dilma Rousseff foi eleita, em 2010, a primeira mulher presidente do Brasil, tomando posse no cargo no início do ano seguinte, junto com o vice-presidente Michel Temer, do Partido do Movimento Democrático Brasileiro (PMDB).

${ }^{5}$ Proposta de emenda constitucional que limitava o poder investigatório do Ministério Público.
} 
grandes empreiteiras, operadores financeiros e políticos de vários partidos da oposição e da situação (Tatagiba, 2018), incluindo o PT, ao qual Rousseff é filiada.

Esses fatos provocaram uma instabilidade no cenário político nacional e a queda de popularidade da presidente. No entanto, após acirrada disputa com o candidato Aécio Neves, do Partido da Social Democracia Brasileira (PSDB), Dilma Rousseff se reelegeu em outubro de 2014 e tomou posse em $1^{\circ}$ de janeiro do ano seguinte. Pouco tempo depois, suas relações com o Congresso Nacional iriam se desgastar com a vitória de Eduardo Cunha (PMDB) para a Presidência da Câmara dos Deputados, ao derrotar o candidato apoiado pelo governo (Ibid.). Paralelamente, a crise econômica favorecia a realização de outras mobilizações pelo país, entre elas a de março de 2015, em que mais de um milhão de pessoas voltaram às ruas para criticar a gestão de Rousseff, pedindo sua saída da Presidência. Diante disso, o vice-presidente Michel Temer foi nomeado articulador político do governo, em busca de melhorar o diálogo da Presidência com o Congresso Nacional e com o principal partido de centro: o PMDB. Entretanto, no auge das manifestações e com o avanço da Operação Lava Jato, Cunha romperia formalmente com o Planalto, aproximando-se dos oposicionistas e, mais adiante, acolhendo um dos pedidos de abertura do processo de impeachment contra a presidente (Ibid.). ${ }^{6}$

Logo após, Temer tornou pública uma carta a Rousseff na qual afirmava ter sido um "vice decorativo" ao longo da gestão da presidente. Em seguida, nos primeiros meses de 2016, foi a vez de o PMDB romper com o governo. Diante desse cenário, em março de 2016, na maior mobilização política da história recente do país, três milhões e seiscentas mil pessoas (de acordo com a Polícia Militar) foram às ruas para protestar contra Dilma Rousseff, o ex-presidente Lula e o Partido dos Trabalhadores. ${ }^{7}$

Nesse contexto, a Avenida Paulista, importante artéria da cidade de São Paulo, se tornou o grande "palco" do impeachment e o foco central das manifestações, nas quais se viam cartazes apoiando a Polícia Federal, o Ministério Público e o juiz Sérgio Moro (principal protagonista da Operação Lava Jato); o verde e amarelo da bandeira brasileira; o "Pato da Fiesp"; e o boneco "Pixuleco". Outro símbolo dos protestos foi o "panelaço" - ato

\footnotetext{
${ }^{6}$ O pedido foi protocolado na Câmara dos Deputados pelos juristas Hélio Bicudo, Miguel Reale Júnior e Janaina Paschoal. Segundo eles, a presidente Dilma Rousseff cometeu "crime de responsabilidade ao praticar as chamadas pedaladas fiscais e gastar recursos sem a devida autorização prévia do Congresso" (Pereira, 2015, p. 56).

${ }^{7}$ Disponível em http://www.fgv.br/cpdoc/acervo/dicionarios/verbete-biografico/dilma-vana-rousseff. Acesso em: 08 fev. 2021.
} 
de bater panelas em janelas ou sacadas dos edifícios -, acompanhando, muitas vezes, os pronunciamentos de Rousseff (Tatagiba, 2018).

O processo de impeachment da presidente, por sinal, seria aprovado pela Câmara dos Deputados em abril de 2016 e, em seguida, foi admitida sua abertura no Senado Federal, culminando com o afastamento de Rousseff da função por 180 dias, o que levou Temer a assumir como presidente interino. Na votação decisiva do impeachment, embora Dilma Rousseff não tenha perdido seus direitos políticos - o que lhe permitia voltar a concorrer a cargos eletivos -, o Senado aprovou o impedimento da continuidade do seu mandato, decidindo, em agosto, afastá-la, em definitivo, da Presidência da República.

Com a cassação do mandato de Rousseff pelo Senado Federal, Michel Temer assumiu o cargo de presidente da República, tornando-se alvo de protestos imediatamente após a sua posse. ${ }^{8}$ Devido à instabilidade econômica que assolava o país, o chefe do Executivo propôs uma série de reformas impopulares, a fim de reduzir os gastos públicos e recuperar a economia (Campos, Coimbra e Oliveira, 2018). A primeira delas, a PEC 55, que impunha limites no aumento dos gastos futuros do governo federal, provocou manifestações em novembro de 2016, porém obteve aprovação no mês seguinte, demonstrando o apoio da base aliada do governo Temer (Ibid.).

Vale mencionar que em setembro do mesmo ano, no chamado Dia Nacional de Paralisação e Mobilização das Categorias, convocado por centrais sindicais, milhares de pessoas saíram às ruas contra as reformas trabalhista ${ }^{9}$ e da Previdência ${ }^{10}$ defendidas por $^{\circ}$ Temer. ${ }^{11}$ Para os movimentos de esquerda, essas reformas significavam "um retrocesso em termos de perda de direitos dos trabalhadores, garantidos tanto pela CLT [Consolidação das Leis do Trabalho] como pela Constituição de 1988" (Ibid., p. 160).

Essas medidas impopulares, aliadas às denúncias do envolvimento dele e de integrantes do seu governo em esquemas de corrupção, contribuíram, ainda mais, para seus baixos índices de popularidade e foram o estopim para manifestações pedindo sua saída da

\footnotetext{
${ }^{8}$ Disponível em http://www.fgv.br/cpdoc/acervo/dicionarios/verbete-biografico/michel-miguel-elias-temerlulia. Acesso em: 10 mar. 2021.

${ }^{9}$ A reforma trabalhista, contudo, foi aprovada em julho de 2017 e demonstrou, novamente, a força da base aliada governista (Campos, Coimbra e Oliveira, 2018).

${ }^{10}$ A reforma da Previdência, considerada igualmente fundamental pelo governo para estabilizar a economia e reduzir os gastos públicos, foi deixada para 2018, mas acabou não sendo votada em razão de muitos políticos temerem ser rejeitados em ano de eleição, haja vista a impopularidade da medida.

${ }^{11}$ Disponível em http://www.fgv.br/cpdoc/acervo/dicionarios/verbete-biografico/michel-miguel-elias-temerlulia. Acesso em: 10 mar. 2021.
} 
Presidência (lbid.). Temer, no entanto, permaneceu no cargo até o fim do seu mandato, em $1^{\underline{o}}$ de janeiro de 2019, quando tomou posse o presidente recém-eleito Jair Bolsonaro.

O primeiro ano da gestão de Bolsonaro seria marcado pelo enfrentamento da crise econômica e do desemprego, pela defesa de uma ampla agenda de reformas, pela eleição das redes sociais como canal direto de comunicação e pela coleção de uma série de atitudes e declarações polêmicas. Além disso, o presidente colocou em prática o discurso armamentista adotado em sua campanha, ao assinar decretos para facilitar a posse e o porte de armas de fogo no país (pautas por ele assumidas quando era deputado federal), que seriam criticados pela oposição. ${ }^{12}$ Bolsonaro foi também alvo de críticas no que se refere à política ambiental do seu governo, protagonizando vários desentendimentos com organizações não governamentais, pesquisadores, políticos estrangeiros (entre eles o presidente francês Emmanuel Macron e a chanceler alemã Angela Merkel) e até com o ator estadunidense Leonardo DiCaprio. ${ }^{13}$

Por fim, vale mencionar que, de modo diferente dos governos que o antecederam, Bolsonaro não conta com uma base de apoio articulada no Congresso, porém terminou 2019 com uma vitória expressiva: a aprovação da reforma da Previdência, a mais ampla da história recente do país. Em síntese, a década de 2010 foi um período de grande turbulência política nacional, o que acabou se refletindo na revalorização da ideia de "resistência" na sociedade civil. Tais fatos iriam ser retratados nos desfiles das escolas de samba do Rio de Janeiro na forma de enredos reagindo à crise e às imposições políticas, como veremos a seguir.

\section{As escolas de samba do Rio de Janeiro e a política brasileira (2011-2020): uma mistura que deu samba}

Os acontecimentos políticos ocorridos no Brasil entre 2011 e 2020 repercutiram em toda a sociedade, incentivando e refletindo o desejo de mudanças no país. A cultura popular iria dialogar com esses desejos e tensões em suas diferentes manifestações, dentre as quais se destaca o carnaval e, em particular, os desfiles das escolas de samba do Rio de Janeiro.

Produtos de intensos diálogos e negociações entre os interesses de múltiplas instâncias da sociedade, as escolas de samba cariocas vêm se apresentando como um lugar

\footnotetext{
12 Disponível em https://g1.globo.com/retrospectiva/2019/noticia/2019/12/27/retrospectiva-2019-relembre-oque-marcou-o-primeiro-ano-do-governo-bolsonaro.ghtml. Acesso em: 12 abr. 2021.

${ }^{13}$ Disponível em https://g1.globo.com/retrospectiva/2019/noticia/2019/12/27/retrospectiva-2019-relembre-oque-marcou-o-primeiro-ano-do-governo-bolsonaro.ghtml. Acesso em: 12 abr. 2021.
} 
de extensa discussão política desde seus primeiros anos, mas foi a partir das últimas décadas do século $X X$ que o tema político, no sentido estrito, apareceu com mais destaque em seus enredos. ${ }^{14}$ Um exemplo disso é o desfile de 1985 da escola de samba Caprichosos de Pilares, realizado um ano após a derrota do projeto que buscava restabelecer eleições para presidente no país (Grillo, 2016, p. 6). Apresentando o enredo “E por falar em saudade", 15 a escola reclamava da inflação na época e lembrava, na letra do seu samba, ${ }^{16}$ o tempo em que "diretamente, o povo escolhia o presidente".

Na década seguinte, com a retomada da democracia, a estabilidade econômica e os numerosos patrocínios, as escolas de samba procuraram frear seu teor crítico. Isso não impediu, contudo, que a Unidos do Cabuçu trouxesse, em 1990 (ano seguinte ao da eleição do presidente Fernando Collor), a desconfiança no título de seu enredo, ${ }^{17}$ que perguntava: “Será que votei certo para presidente?"(Ibid.).

Outro exemplo dessa aproximação das agremiações com o governo federal ocorreu em 2003, quando uma das alegorias do desfile da Beija-Flor de Nilópolis prestou uma homenagem explícita ao presidente Lula (figura 1), recém-eleito chefe do Executivo. ${ }^{18}$

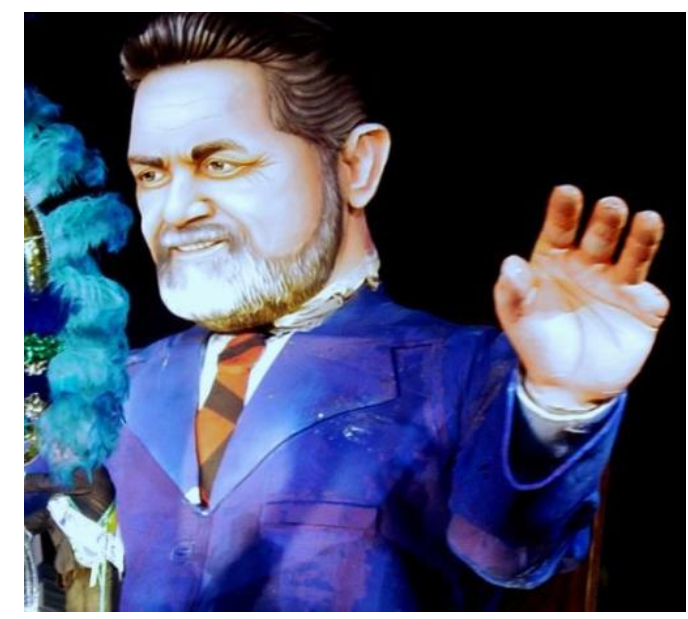

Figura 1: Detalhe da alegoria em homenagem a Lula no desfile da Beija-Flor, em 2003. Fonte: Arquivo pessoal do fotógrafo Wigder Frota.

\footnotetext{
${ }^{14}$ Sobre o tema, ver Almeida (2020), que disseca, com riqueza de dados e detalhes, as críticas políticas presentes nos enredos das escolas de samba cariocas, principalmente na década de 1980.

${ }^{15}$ Concebido pelos carnavalescos Luiz Fernando Reis e Flávio Tavares.

${ }^{16}$ De Almir Araújo, Marquinhos Lessa, Hércules Corrêa, Balinha e Carlinhos de Pilares.

${ }^{17}$ Assinado pelo carnavalesco Beto Sol.

${ }^{18}$ Nesse desfile, um dos destaques da escola, o cantor Neguinho da Beija-Flor, anunciava: "A esperança venceu o medo", mesma frase dita pelo presidente Lula ao vencer a eleição (Grillo, 2016, p. 6).
} 
Quase uma década depois, em 2012, Lula voltaria a ser exaltado no carnaval do Rio de Janeiro, dessa vez na apresentação da Acadêmicos do Grande Rio, junto com a presidente Dilma Rousseff, ambos representados pela velha guarda da escola: ${ }^{19}$ as mulheres trajando o vestuário vermelho característico de Rousseff, com uma faixa presidencial (figura 2); os homens vestindo terno em alusão ao ex-presidente.

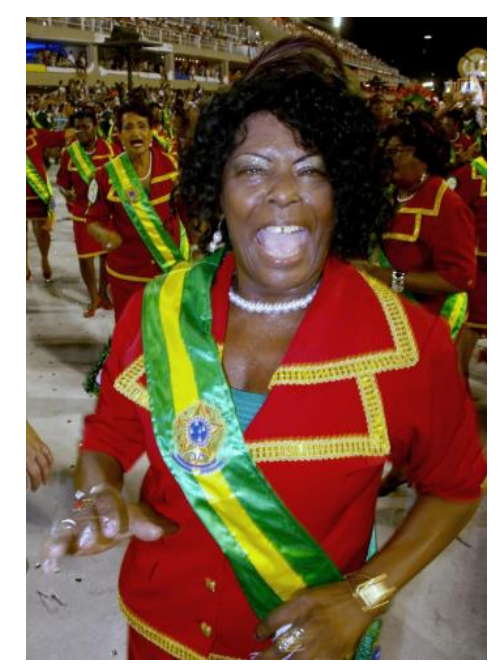

Figura 2: Componente da velha guarda da Acadêmicos do Grande Rio, encarnando a presidente Dilma Rousseff no desfile da escola em 2012. Fonte: Arquivo pessoal do fotógrafo Wigder Frota.

As escolas de samba começaram, dessa forma, a reavivar seu diálogo com o governo, ou seja, a questão política ampliou sua ascendência a partir da ideia de revalorização da "resistência" nos desfiles carnavalescos, abrangendo práticas e significações constituídas e constituintes do processo social maior da realidade brasileira.

A relação entre o poder constituído e as escolas de samba seria notada também no desfile da São Clemente de 2016, por meio do enredo “Mais de mil palhaços no salão!”, 20 sobre o universo do circo. A agremiação contava com uma ala ${ }^{21}$ simbolizando a insatisfação popular com a presidente Dilma Rousseff. Nela, foliões caracterizados como chefes de cozinha usavam narizes de palhaço e teatralizavam um "panelaço" (figura 3), em sincronia

\footnotetext{
${ }^{19}$ A chamada Ala da Velha Guarda reúne os componentes mais idosos de cada escola de samba, geralmente vestidos com ternos, tailleurs, fraques ou indumentárias que remetem à respeitabilidade e "tradicionalidade" do grupo.

${ }^{20}$ Criado pela carnavalesca Rosa Magalhães.

${ }^{21}$ Ala é um grupo de pessoas que se reúne para desfilar em uma escola de samba, usando, quase sempre, uma mesma fantasia e narrando uma pequena parte do enredo.
} 
com a batida dos instrumentos de percussão (O Globo, 2016b, p. 3), insinuando os protestos barulhentos da classe média contra Rousseff durante seus pronunciamentos.

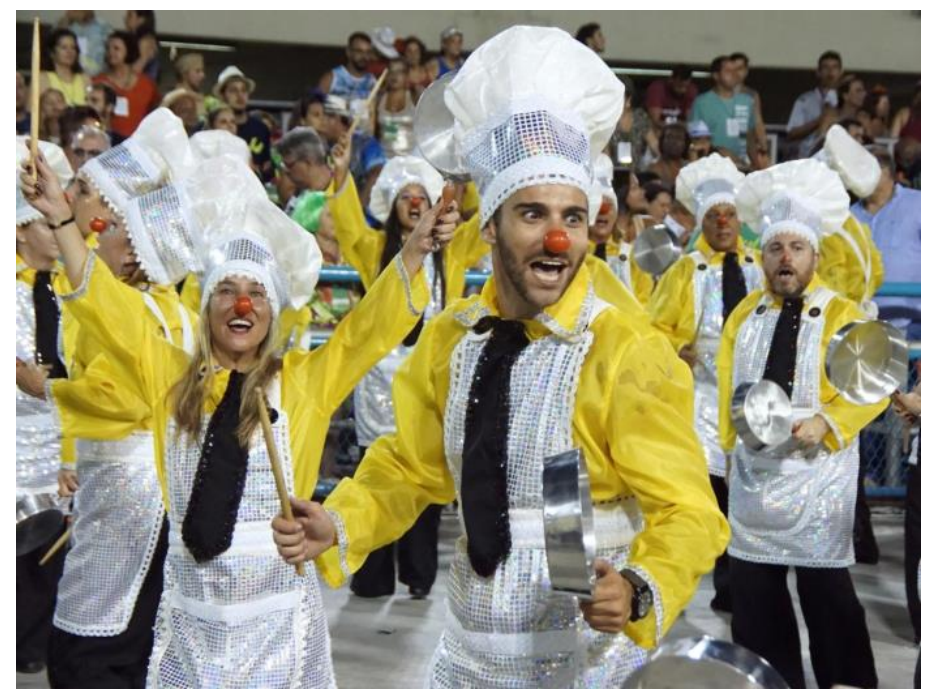

Figura 3: Desfilantes retratando chefes de cozinha em encenação de um "panelaço" na apresentação da São Clemente, em 2016. Fonte: Arquivo pessoal do fotógrafo Wigder Frota.

Ainda em 2016, a Mocidade Independente de Padre Miguel abordou, em seu enredo "O Brasil de la Mancha", 22 os escândalos da Operação Lava Jato, ao associar a Petrobras ${ }^{23}$ à corrupção (O Globo, 2016a, p. 9). A escola retratava a Lava Jato em sua comissão de frente, ${ }^{24}$ da qual faziam parte dançarinos personificando corruptos engravatados sem cabeça (figura 4) e um moinho que se transformava em plataforma de exploração de petróleo. Em certo momento do desfile, esses corruptos eram presos por Dom Quixote e Sancho Pança, ato saudado por um cavaleiro que empunhava a bandeira do Brasil (Ibid.).

\footnotetext{
22 Desenvolvido pelos carnavalescos Alexandre Louzada e Edson Pereira.

${ }^{23}$ Embora fosse patrocinadora dos desfiles do Grupo Especial e tenha liberado, na época, o valor de R\$2,4 milhões para ser dividido entre as principais escolas de samba do Rio de Janeiro, a Petrobras foi apresentada de forma negativa pela Mocidade Independente nesse desfile (O Globo, 2016a, p. 9).

${ }^{24}$ Grupo performático que abre o desfile de cada escola de samba. 


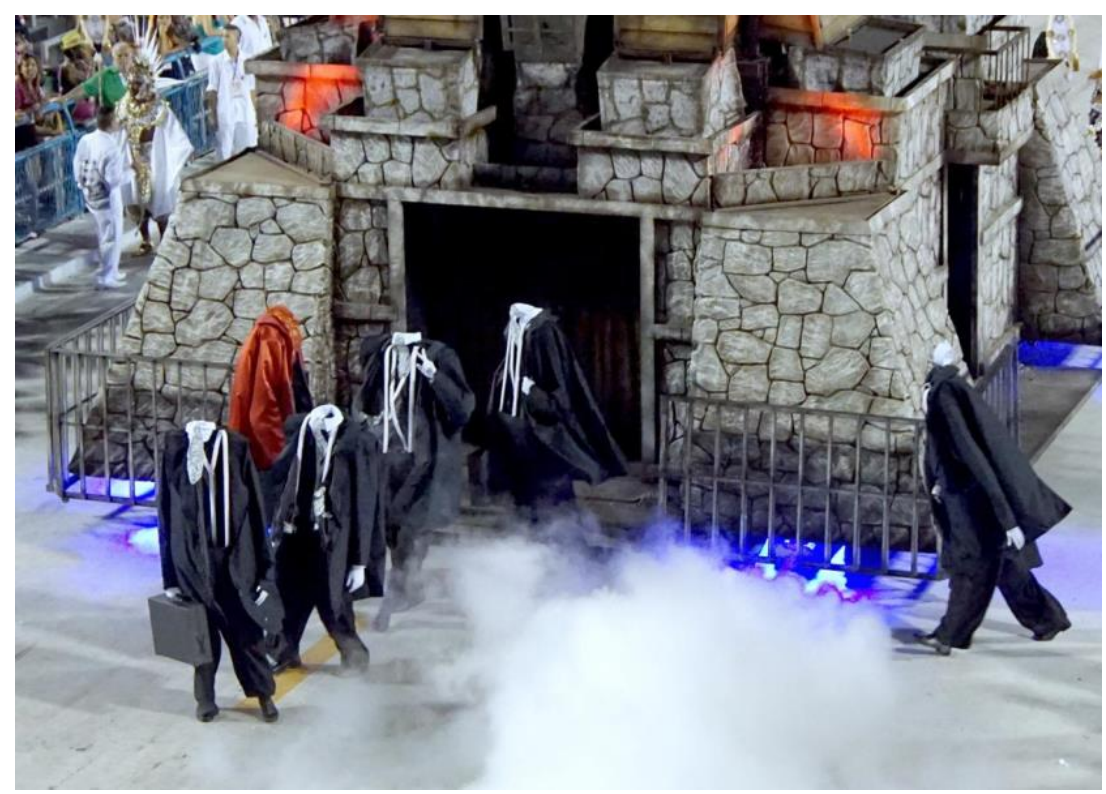

Figura 4: Integrantes da comissão de frente da Mocidade Independente de Padre Miguel representaram políticos e empresários corruptos no desfile de 2016, em referência aos criminosos da Operação Lava Jato. Fonte: Arquivo pessoal do fotógrafo Wigder Frota.

Em outra menção aos escândalos de corrupção no Brasil, o carro abre-alas ${ }^{25}$ da Mocidade Independente mostrava uma espécie de "mar de lama", retratado pelo óleo extraído de uma plataforma alegórica de petróleo. ${ }^{26} \mathrm{Em}$ adição, o desfile da agremiação trouxe alas dramatizando a inflação no país e exibiu, à frente de uma de suas alegorias, ratos enormes e notas de dólar como representação dos "roedores" do dinheiro público.

Percebemos, assim, o diálogo do carnaval com a política contemporânea, a partir de sua dimensão crítica e satírica. Marcados por suas sínteses e contradições, negociações e contestações, os desfiles das escolas de samba apresentavam-se como palco no qual se expressavam, significativamente, relações sociais, ampliado para além da visão estrita de "produção" e "reprodução" da vida real, com o poder de modificar a realidade que refletia, ou seja, atuando na construção da sociedade e da cultura. Ao interagir com a trama política da época em seus desfiles, teatralizando as inquietações e indignações da sociedade e criticando os desmandos de seus governantes, as agremiações se destacavam e se emancipavam do poder político vigente.

\footnotetext{
${ }^{25}$ O carro abre-alas é a primeira grande alegoria de cada escola de samba, responsável por "abrir" o desfile. Quase sempre apresenta o nome da agremiação ou o seu principal símbolo.

${ }^{26}$ Apesar das críticas à Petrobras, os carros alegóricos da Mocidade Independente eram empurrados por homens com macacões de petroleiros, nos quais se via o logotipo da empresa (Ibid.).
} 
Seguindo essa linha de abordagem, os desfiles das escolas de samba de 2018 foram marcados por temas de engajamento social e político, como aqueles apresentados pela Paraíso do Tuiuti, Estação Primeira de Mangueira e Beija-Flor de Nilópolis. A Paraíso do Tuiuti, por meio do enredo “Meu Deus, meu Deus, está extinta a escravidão?", 27 explorou os problemas sociais resultantes da escravidão no Brasil, bem como a fragilidade das relações de trabalho contemporâneas (Briso e Bacelar, 2018, p. 8). Uma de suas alas, denominada "Manifestoches", mesclava referências ao criticar as manifestações pelo impeachment da ex-presidente Dilma Rousseff (O Globo, 2018b, p. 5), mostrando desfilantes batendo panelas e sendo "manipulados" por mãos gigantescas, como se fossem marionetes, trajados com camisas da seleção brasileira e montados sobre patos amarelos (figura 5), em alusão ao imenso pato de borracha inflável da Fiesp, entidade que apoiou a destituição da presidente Rousseff.

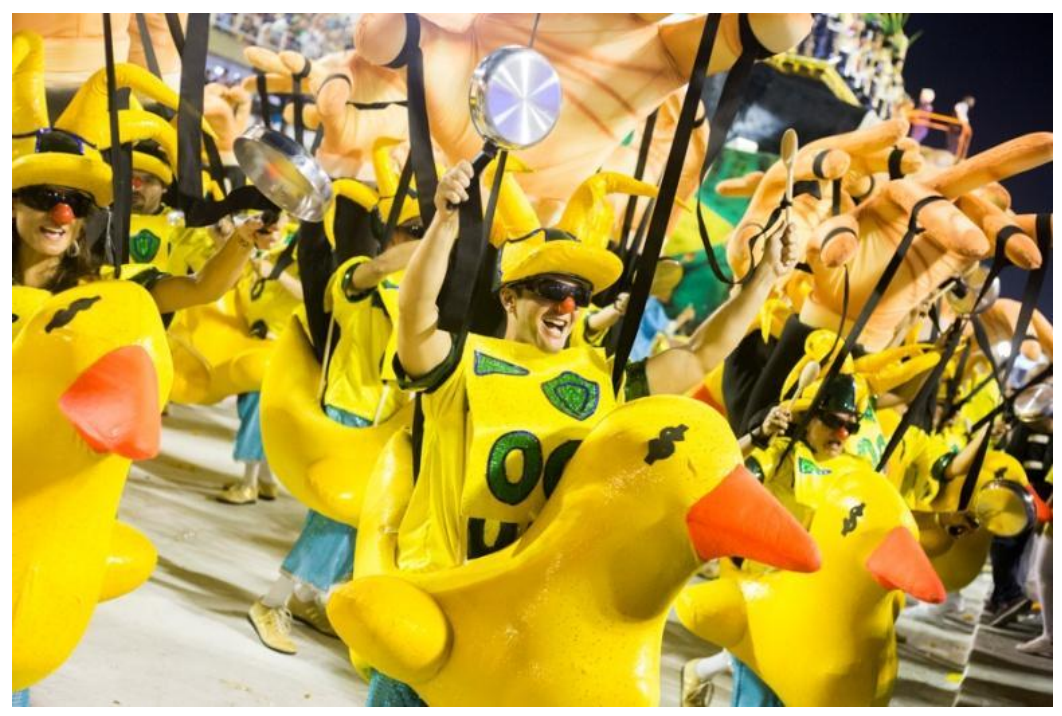

Figura 5: Foliões dramatizaram um "panelaço" no desfile da Paraíso do Tuiuti, em 2018, trajados com camisas da seleção brasileira e montados sobre patos de borracha. Fonte: Arquivo pessoal do fotógrafo Ewerton Pereira.

Outra ala trazia componentes fantasiados de operários/guerreiros empunhando escudos na forma de carteiras de trabalho semidestruídas (figura 6), em crítica à reforma trabalhista defendida e aprovada na gestão do então presidente Michel Temer, este tipificado no desfile como vampiro com faixa presidencial (Briso e Bacelar, 2018, p. 8). Ou

${ }^{27}$ Concebido pelo carnavalesco Jack Vasconcelos. 
seja, um carnaval que criticava o governo Temer e questionava o modo pelo qual o político chegou à Presidência.

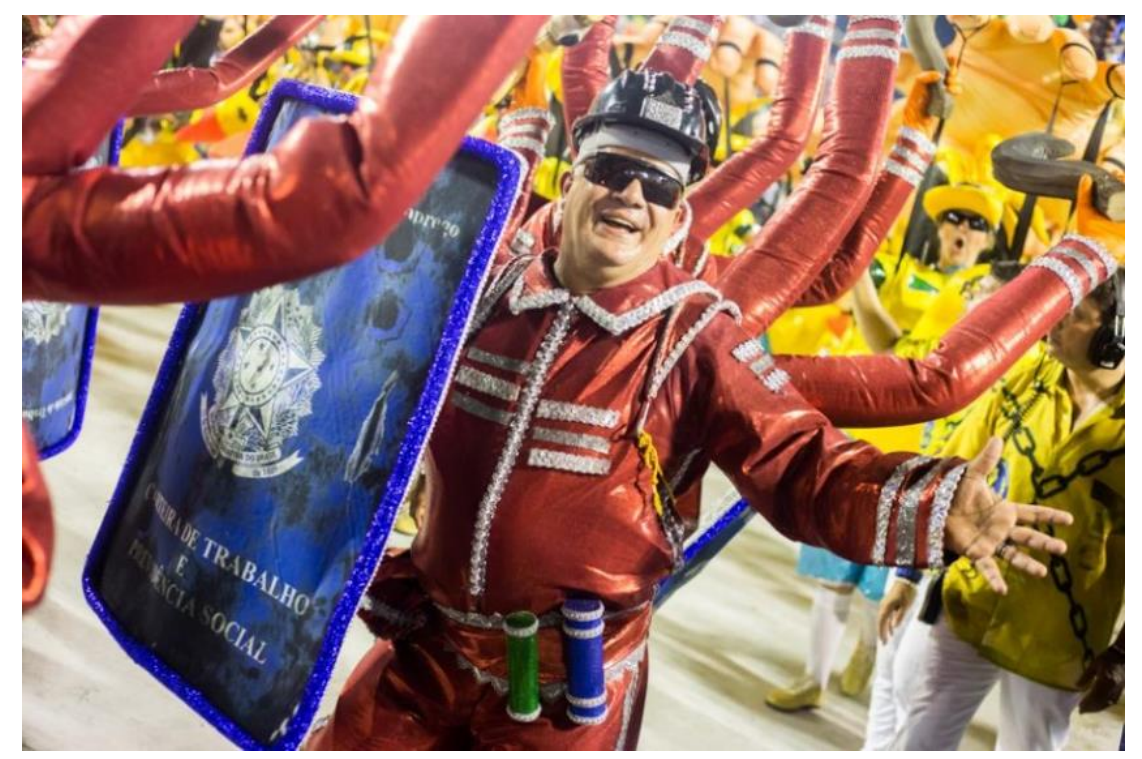

Figura 6: Folião empunhando escudo na forma de carteira de trabalho semidestruída durante o desfile da Paraíso do Tuiuti, em 2018. Fonte: Arquivo pessoal do fotógrafo Ewerton Pereira.

Já a Estação Primeira de Mangueira, com o enredo "Com dinheiro ou sem dinheiro, eu brinco!", ${ }^{28}$ criticava o corte de verbas para as escolas de samba do Grupo Especial do Rio de Janeiro, decretado pelo prefeito da cidade, o bispo da Igreja Universal do Reino de Deus, Marcelo Crivella (O Globo, 2018c, p. 3), cuja postura pouco simpática ao carnaval ${ }^{29}$ foi duramente criticada pelos foliões. Em um dos carros alegóricos da agremiação, o prefeito era caracterizado como um boneco da malhação de Judas, ${ }^{30}$ "enforcado" com uma placa no pescoço, na qual se lia a frase "Pega no ganzá", uma alusão às falsas promessas por ele feitas aos sambistas ao longo de sua campanha eleitoral de $2016^{31}$ (O Globo, 2018b, p. 5). No mesmo carro, uma faixa em tom provocativo apresentava os seguintes dizeres: “Olhai por nós!... O

\footnotetext{
${ }^{28}$ Idealizado pelo carnavalesco Leandro Vieira.

${ }^{29}$ O prefeito chegou a se ausentar do país no período carnavalesco.

${ }^{30}$ A "malhação de Judas" é uma brincadeira popular brasileira característica do Sábado de Aleluia, em que um boneco representando algum personagem criticado pela comunidade é pendurado pelo pescoço antes de ser destruído a golpes de porretes e, posteriormente, queimado.

${ }^{31} \mathrm{Na}$ época pré-eleitoral, o ainda candidato, para conquistar o voto dos sambistas e mostrar que gostava de carnaval, entoaria o trecho de um famoso samba-enredo da escola de samba Acadêmicos do Salgueiro: “Olelê! Olalá! / Pega no ganzê / Pega no ganzá!".
} 
prefeito não sabe o que faz"32 (figura 7). Além disso, vários versos do samba-enredo da Mangueira ${ }^{33}$ expressavam o descontentamento da escola com o prefeito carioca: "Chegou a hora de mudar / Erguer a bandeira do samba / Vem a luz à consciência / Que ilumina a resistência dessa gente bamba / ... / Eu sou Mangueira, meu senhor, não me leve a mal / Pecado é não brincar o carnaval!".

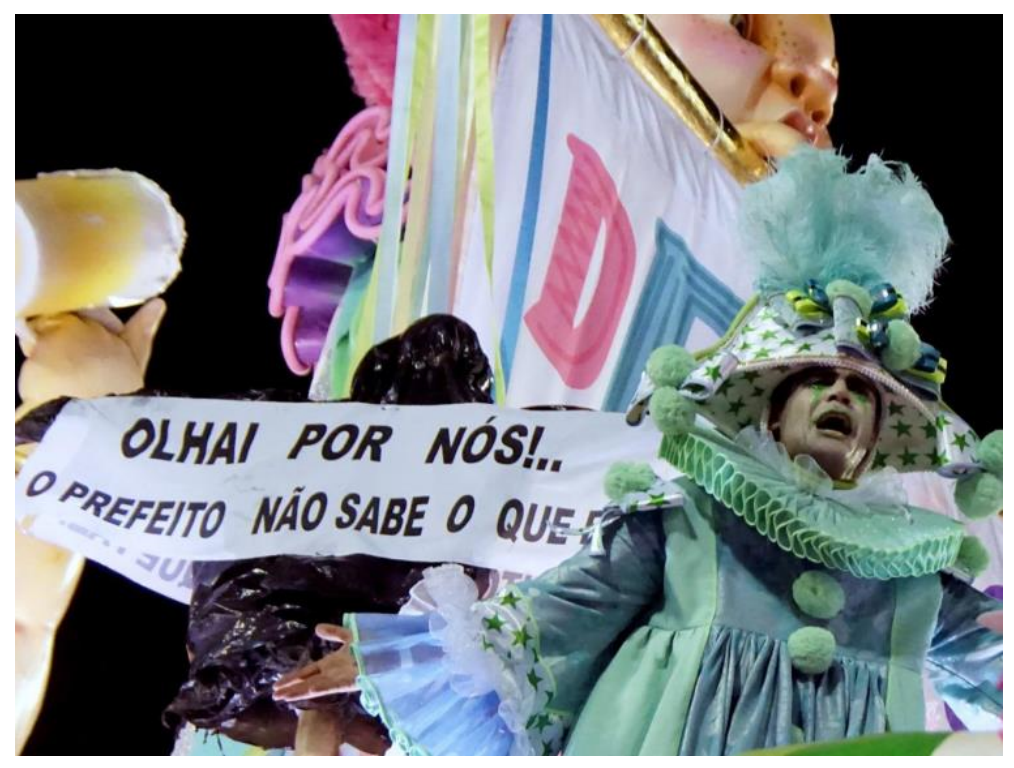

Figura 7: O desfile da Estação Primeira de Mangueira, em tom de crítica ao prefeito Marcelo Crivella, exibiu uma faixa com os seguintes dizeres: "Olhai por nós, o prefeito não sabe o que faz". Fonte: Arquivo pessoal do fotógrafo Wigder Frota.

A Beija-Flor de Nilópolis, por sua vez, apresentou o enredo "Monstro é aquele que não sabe amar. Os filhos abandonados da pátria que os pariu", ${ }^{34}$ criticando as mazelas do país e, especialmente, as da cidade do Rio de Janeiro, ao reproduzir fatos noticiados pela imprensa, tais como simulação de arrastões, morte de policiais e tiros dentro de sala de aula (O Globo, 2018a, p. 1). Uma das alegorias da escola mostrava uma representação do prédio

\footnotetext{
${ }^{32}$ A faixa, presa a uma pequena imagem do Cristo Redentor coberta com plástico preto, fazia referência cifrada a uma polêmica envolvendo a famosa escultura de Jesus Cristo, símbolo do Rio de Janeiro. No carnaval de 1989, a Beija-Flor de Nilópolis havia sido proibida de desfilar com a imagem da estátua apresentando Cristo como um mendigo. A solução encontrada pelo carnavalesco e pelo diretor de carnaval da escola foi cobrir a escultura com plástico preto e prender sobre ele uma faixa com os dizeres: "Mesmo proibido, olhai por nós".

${ }^{33}$ Dos autores Lequinho, Júnior Fionda, Alemão do Cavaco, Gabriel Machado, Wagner Santos, Gabriel Martins e Igor Leal.

${ }^{34}$ Elaborado por Marcelo Misailidis, Laíla, Cid Carvalho, Bianca Behrends, Victor Santos, Rodrigo Pacheco e Léo Mídia.
} 
da Petrobras, que se transformava em uma favela onde eram exibidas cenas chocantes do cotidiano, entre elas a personificação de traficantes apontando fuzis para a plateia. À frente desse carro, um imenso rato simbolizava os "maus governantes" do país (figura 8). Havia também, nessa apresentação, desfilantes rotulados de "empreiteiros associados" (figura 9), barris de petróleo lembrando os escândalos na Petrobras e foliões carregando malas de dinheiro (Ibid., p. 7). Em outra ala, a escola reconstituiu o evento que ficou conhecido na imprensa brasileira como "A farra dos guardanapos": um banquete em Paris no qual secretários e empresários ligados ao então governador do Rio de Janeiro, Sérgio Cabral, festejavam com guardanapos amarrados na cabeça ${ }^{35}$ (O Globo, 2018c, p. 3). Ainda nesse desfile da Beija-Flor, a ideia de "resistência" foi reforçada em alguns versos do seu sambaenredo: ${ }^{36}$ "Meu canto é resistência / No ecoar de um tambor / Vem ver brilhar / Mais um menino que você abandonou".

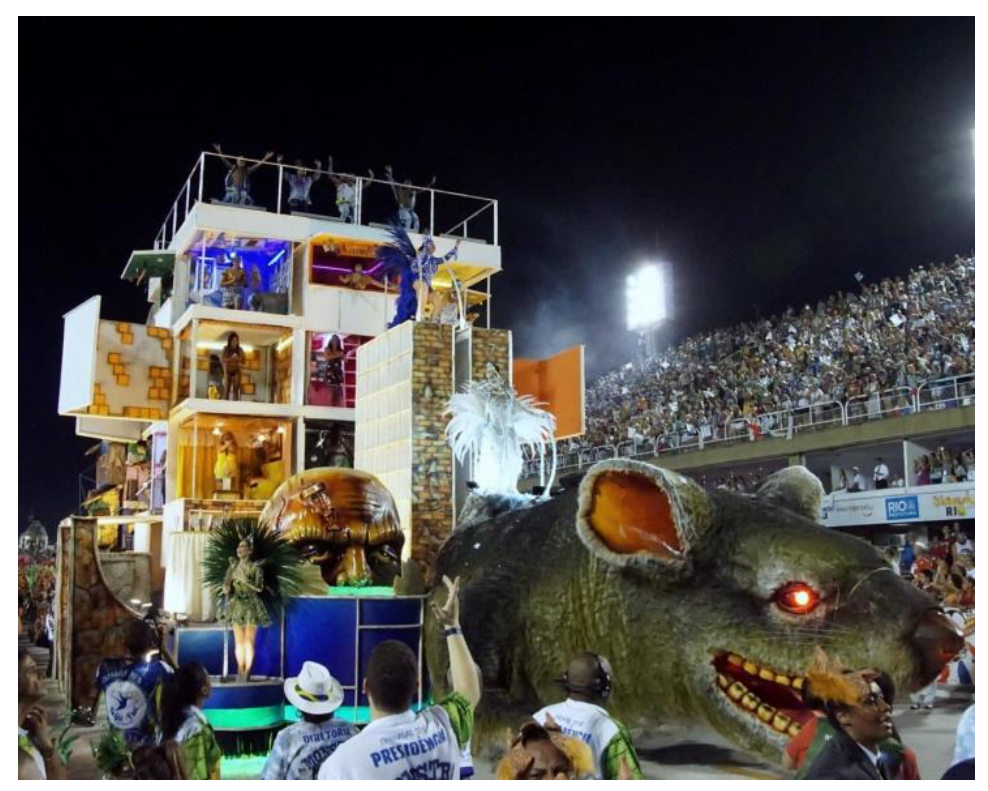

Figura 8: Um enorme rato, à frente de uma estrutura alegórica inspirada no prédio da Petrobras, espelhava os "maus governantes" do país no desfile da Beija-Flor, em 2018. Fonte: Arquivo pessoal do fotógrafo Wigder Frota.

\footnotetext{
35 De acordo com Barsetti (2018), essa festa em Paris, realizada em 2009, marcou a derrocada do governo de Sérgio Cabral, preso em 2016. Acusados de participação em esquemas de corrupção (sob o comando de Cabral) no governo do Estado do Rio de Janeiro, "quase todos os principais personagens da Farra dos Guardanapos se tornam alvos dos desdobramentos no Rio da Operação Lava Jato e também são presos ou detidos temporariamente" (Ibid., p. 156).

${ }^{36}$ De autoria de Di Menor BF, Kiraizinho, Diego Oliveira, Bakaninha Beija-Flor, J.J. Santos, Julio Assis e Diogo Rosa.
} 


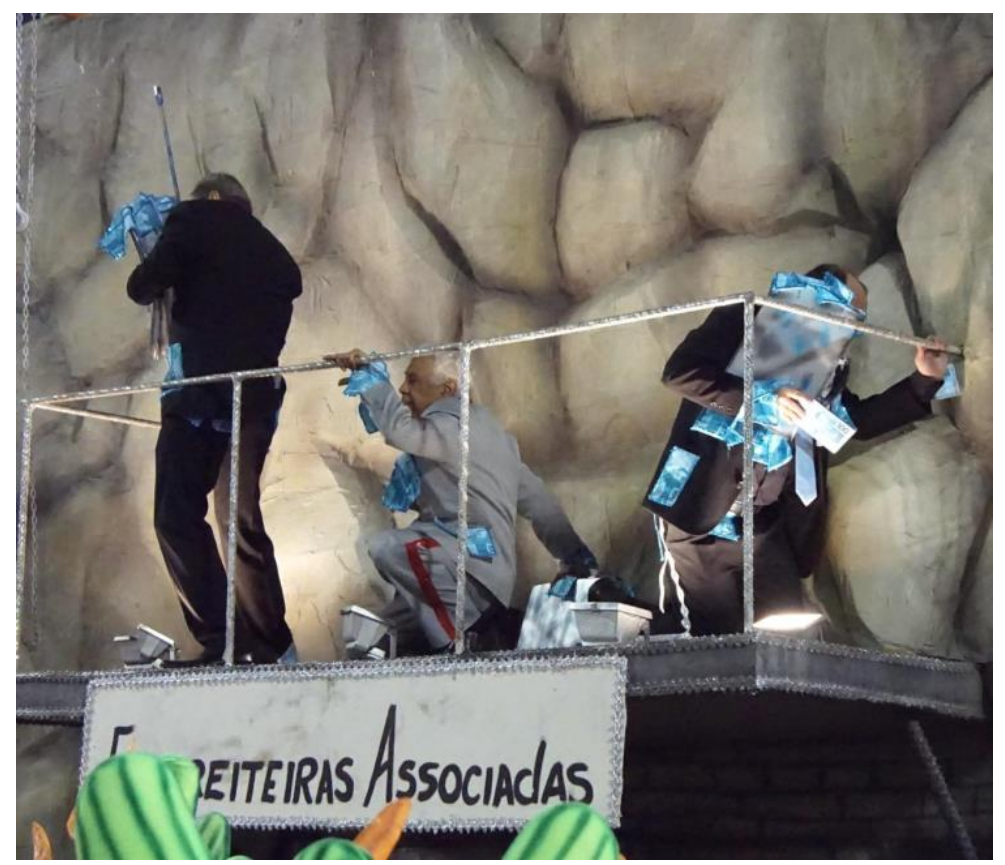

Figura 9: Com malas repletas de dinheiro, desfilantes encarnaram empresários rotulados de "empreiteiros associados" no desfile da Beija-Flor, em 2018, em menção à Operação Lava Jato e ao esquema de corrupção no país. Fonte: Arquivo pessoal do fotógrafo Wigder Frota.

Evidencia-se, dessa forma, o fato de que os desfiles das escolas de samba, em pleno ano de eleição, continuavam a se voltar para as insatisfações do povo em relação a autoridades dos três níveis do governo brasileiro (municipal, estadual e federal), refletindo as duras críticas da sociedade nesse momento de instabilidade política nacional, consequências do pensamento contemporâneo.

Em época relativamente mais recente, observa-se a crítica política em pelo menos dois momentos do carnaval carioca. O primeiro deles, no desfile da São Clemente (2020), com base no enredo satírico "O conto do vigário", ${ }^{37}$ no qual a escola reviveu a história "moderna" do Brasil. Em uma das alegorias, o ator e humorista Marcelo Adnet (um dos autores do samba-enredo da agremiação), trajando um terno azul-brilhante e uma gravata verdeamarela, encarnou o presidente Jair Bolsonaro ao fazer flexões de braço e disparar uma arma imaginária, cenas já protagonizadas pelo chefe do Executivo. Na mesma alegoria, cartazes exibiam a expressão "Tá ok?" - bordão de Bolsonaro - e a frase "foi o Leonardo DiCaprio", ligada à fala do presidente "acusando" DiCaprio de "financiar" as queimadas na Amazônia.

${ }^{37}$ Assinado pelo carnavalesco Jorge Silveira. 
Vale ressaltar ainda, nesse desfile, os ritmistas fantasiados de "laranja"; 38 os diretores da escola caracterizados como policiais federais; e um componente trajado de "Cabral no presídio de Bangu", evocando a prisão do ex-governador do Rio de Janeiro, Sérgio Cabral (O Globo, 2020, p. 3).

De modo similar, o carnaval da Acadêmicos de Vigário Geral, escola de samba do Segundo Grupo do Rio de Janeiro, apoiado no enredo também intitulado "O conto do vigário", ${ }^{39}$ criticou Bolsonaro em seu último tripé. ${ }^{40}$ Nele, havia um grande boneco que personificava o palhaço Bozo (apelido dado ao presidente por adversários políticos), usando faixa presidencial e fazendo o símbolo de arma com uma das mãos (figura 10), um dos gestos característicos do presidente. ${ }^{41}$

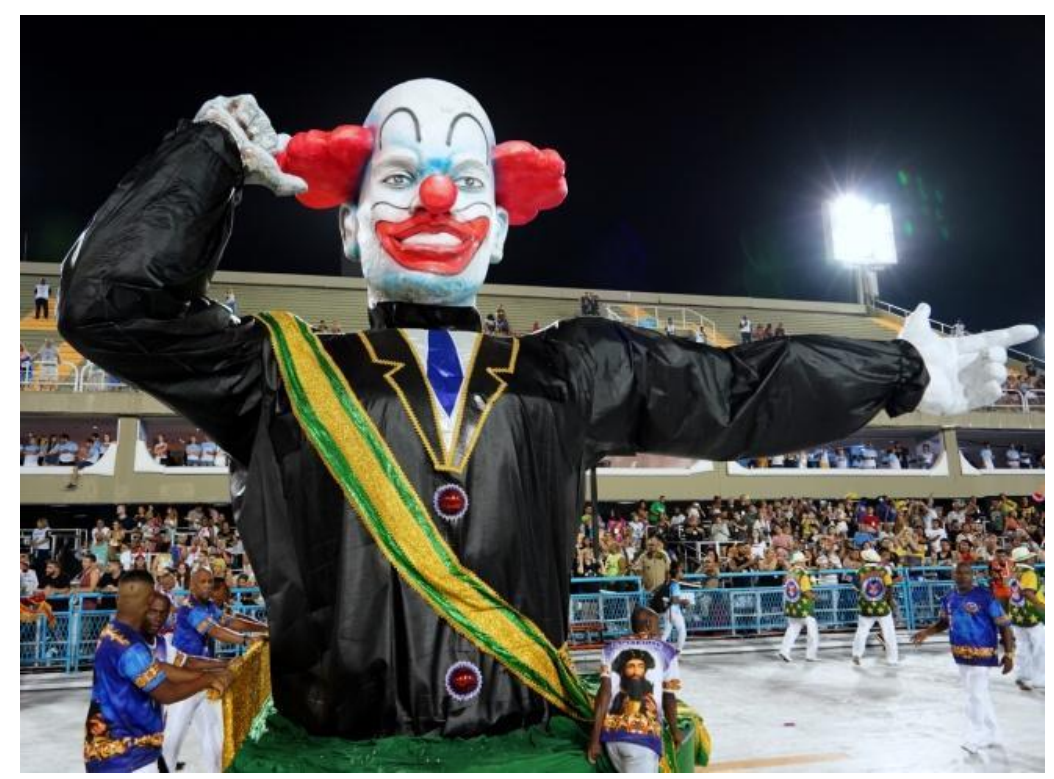

Figura 10: O gesto de disparar uma arma imaginária, típico do presidente Jair Bolsonaro, foi reproduzido em um enorme boneco no fim do desfile da Acadêmicos de Vigário Geral, em 2020. Fonte: Arquivo pessoal do fotógrafo Wigder Frota.

\footnotetext{
${ }^{38}$ No Brasil, o termo "laranja" denomina alguém usado para encobrir falcatruas ligadas a desvio de dinheiro e esquemas de corrupção no país, que empresta seu nome e dados pessoais para ocultar a identidade de outras pessoas responsáveis pelo crime.

${ }^{39}$ De autoria dos carnavalescos Alexandre Costa, Lino Sales, Marcus do Val e Rodrigo Almeida.

${ }^{40}$ Tripé é o termo utilizado para designar uma pequena alegoria.

${ }^{41}$ Disponível em https://oglobo.globo.com/rio/carnaval/com-critica-bolsonaro-academicos-de-vigario-geralabre-1-noite-da-serie-em-2020-24265544. Acesso em: 10 fev. 2021.
} 
Observa-se, portanto, o contato entre a esfera do popular e aquela da política, mostrando que o carnaval das escolas de samba dialoga com as instâncias do poder e impõe sua visão particular do mundo, em que as personalidades do governo brasileiro não estão imunes à crítica ou à tipificação nos desfiles, nos quais os enredos críticos revelam o retrato social e político do país.

\section{Resistências}

A política tomou uma grande dimensão no Brasil entre 2011 e 2020, influenciando expressões artísticas diversas como o carnaval do Rio de Janeiro. Esse movimento fez com que a categoria "resistência" começasse a ser revalorizada no contexto dos desfiles das escolas de samba cariocas, que reagiram contra a crise política nacional e as determinações de autoridades em geral, manifestando aspirações de inconformismo e desejo de mudanças. Ou seja, o carnaval das agremiações tornou-se, na época, uma caixa de ressonância do descontentamento popular com os governos federal, estadual e municipal.

Porta-vozes da insatisfação dos brasileiros, por meio de abordagens críticas e protestos irreverentes, os desfiles das escolas de samba desse período se transformaram em lócus de luta política e articularam, simbolicamente, significados da sociedade contemporânea, traduzidos pela interação entre seus diferentes discursos - visuais (fantasias e alegorias) e literários (letras dos sambas e enredos) -, que apresentavam conteúdo histórico-social e se processavam na forma de representações culturais. Esses discursos contribuem para interpretar o carnaval das agremiações como espaço no qual não somente se espelha a realidade social e política do Brasil, mas também se processam e se criam diferentes níveis de significados dessa realidade, expressando aspectos como contradições, articulações, negociações e contestações.

Nesse sentido, a caricatura, a tipificação, a sátira política e a crítica bem ou malhumorada dos fatos inerentes à sociedade são formas de expressão que vêm marcando o diálogo entre o poder hegemônico e aquele da população no carnaval das escolas de samba do Rio de Janeiro.

\section{Referências Bibliográficas}

Almeida, F. R. de. (2020). Crítica política e perspectivas de democracia nas narrativas carnavalescas das escolas de samba do Rio de Janeiro na década de 1980. Dissertação de Mestrado. Programa de Pósgraduação em História. Universidade do Estado do Rio de Janeiro.

Araújo, V. M. M. (2011). Yes, nós temos baianas: o processo de construção da personagem baiana de escola 
de samba no século XX. Dissertação de Mestrado. Programa de Pós-graduação em Artes. Universidade do Estado do Rio de Janeiro.

Archer-Straw, P. (2000). Negrophilia: avant-garde Paris and black culture in the 1920s. New York: Thames and Hudson.

Augras, M. (1998). O Brasil do samba-enredo. Rio de Janeiro: Fundação Getúlio Vargas.

Bakhtin, M. (1998). 'Carnival and the carnivalesque'. In: Storey, J. Cultural theory and popular culture: a reader. Harlow, Essex: Pearson Education Limited, p. 250-259. . (2010). A cultura popular na Idade Média e no Renascimento: o contexto de François Rabelais. São Paulo: Hucitec.

Barsetti, S. (2018). A farra dos guardanapos: o último baile da era Cabral: a história que nunca foi contada. Rio de Janeiro: Máquina de Livros.

Blake, J. (1999). Le tumulte noir: modernist art and popular entertainment in jazz-age Paris, 1900-1930. University Park: The Pennsylvania State University Press.

Briso, C. B.; Bacelar, C. (2018). 'Tuiuti vai do inferno ao paraíso'. O Globo, Rio de Janeiro, ano XCIII, n⿳⺈ 30.873, 15 fev., Matutina, Rio, p. 8.

Cabral, O. (2013). 'O poder acuado'. Veja, São Paulo, edição 2327, ano 46, no 26, 26 jun., p. 66-71.

Cabral, S. (1996). As escolas de samba do Rio de Janeiro. Rio de Janeiro: Editora Lumiar.

Campos, M. M. de; Coimbra, M. R.; Oliveira, L. A. de. (2018). ‘Crise política: uma análise das estratégias de comunicação do governo de Michel Temer (PMDB)'. Aurora: revista de arte, mídia e política, São Paulo, v. 11, n. 32, jun./set., p. 149-167.

Candeia, A.; Araújo, I. (1978). Escolas de samba: a árvore que esqueceu a raiz. Rio de Janeiro: Lidador/Seec.

Cavalcanti, M. L. V. de C. (2008). Carnaval carioca: dos bastidores ao desfile. Rio de Janeiro: Editora UFRJ.

Costa, H. (2000). 100 anos de carnaval no Rio de Janeiro. São Paulo: Irmãos Vitale Editores.

Cunha, M. C. P. (2001). Ecos da folia: uma história social do carnaval carioca entre 1880 e 1920. São Paulo: Companhia das Letras.

DaMatta, R. (1998). Carnavais, malandros e heróis: para uma sociologia do dilema brasileiro. Rio de Janeiro: Rocco.

Ferreira, F. (2004). O livro de ouro do carnaval brasileiro. Rio de Janeiro: Ediouro.

. (2005). Inventando carnavais: o surgimento do carnaval carioca no século XIX e outras questões carnavalescas. Rio de Janeiro: Editora UFRJ.

. (2008). 'Estratégias de sobrevivência: o surgimento das escolas de samba no Brasil de Getúlio Vargas'. In: Pontes Júnior, G.; Pereira, V. H. A. (Orgs.). O velho, o novo, o reciclável Estado Novo. Rio de Janeiro: De Letras, p. 201-214.

. (2012). 'Escolas de samba: uma organização possível'. In: Escritos carnavalescos.

Rio de Janeiro: Aeroplano, p. 172-192. 
Goldwasser, M. J. (1975). O palácio do samba: estudo antropológico da escola de samba Estação Primeira de Mangueira. Rio de Janeiro: Zahar Editores.

Grillo, M. (2016). ‘Na Sapucaí de enredos milionários, política não dá samba'. O Globo, Rio de Janeiro, ano XCI, nº 30.134, 07 fev., Matutina, Primeiro Caderno, p. 6.

Hall, S. (2003). 'Notas sobre a desconstrução do popular'. In: Sovik, L. (Org.). Da diáspora: identidades e mediações culturais. Belo Horizonte: Editora UFMG; Brasília: Representação da Unesco no Brasil, p. 247-264.

Lira Neto. (2017). Uma história do samba. São Paulo: Companhia das Letras.

Marques, M. (2018). A cuíca está roncando: uma abordagem dos aspectos visuais das revistas carnavalescas de Walter Pinto dos anos 40, e seu diálogo com o carnaval carioca. Tese de Doutorado. Programa de Pós-graduação em Artes. Universidade do Estado do Rio de Janeiro.

. (2020). 'Tem bububu no bobobó: o teatro de revista de Walter Pinto e as escolas de samba'. In: Cavalcanti, M. L.; Gonçalves, R. de S. (Orgs.). Carnaval sem fronteiras: as escolas de samba e suas artes mundo afora. Rio de Janeiro: Mauad X, p. 125-151.

Moraes, E. de (1958). História do carnaval carioca. Rio de Janeiro: Civilização Brasileira.

O Globo. (2016a). A noite em que a propina saiu de destaque. Rio de Janeiro, ano XCI, nº 30.136, 09 fev., Matutina, Rio, p. 9.

. (2016b). Rio de Janeiro, ano XCI, no 30.136, 09 fev., 2ª edição, Matutina, Carnaval, p. 3. . (2018a). Rio de Janeiro, ano XCIII, no 30.873, 15 fev., Matutina, p. 1 e 7.

(2018b). O samba que põe o dedo na ferida. Rio de Janeiro, ano XCIII, nº 30.871, 13 fev.,

Matutina, Carnaval, p. 5.

. (2018c). Recado duro da Avenida ecoa na rede. Rio de Janeiro, ano XCIII, no 30.872, 14 fev., Matutina, Rio, pág. 3.

. (2020). O público do Sambódromo não perdeu a piada. Rio de Janeiro, ano XCV, nº 31.613, 25 fev., Matutina, Caderno Especial, p. 3.

Pamplona, F. (2013). O encarnado e o branco. Rio de Janeiro: Novaterra.

Pereira, D. (2015). 'Impeachment não é guerra'. Veja, São Paulo, edição 2455, ano 48, no 49, 09 dez., p. 54-61.

Pereira, L. A. de M. (2004). O carnaval das letras: literatura e folia no Rio de Janeiro do século XIX. Campinas: Editora Unicamp.

Storey, J. (2015). Teoria cultural e cultura popular: uma introdução. São Paulo: Sesc.

Tatagiba, L. (2018). 'Entre as ruas e as instituições: os protestos e o impeachment de Dilma Rousseff'. Lusotopie, v. 17, set., p. 112-135.

Valença, R. T. (1996). Carnaval: para tudo se acabar na quarta-feira. Rio de Janeiro: Relume-Dumará. 